\title{
Behaviour of Bank Share Prices and Their Impact on National Stock Market Indices: \\ Comparing Countries at Different Levels of Economic Development during Recessionary and Non-Recessionary Periods
}

\author{
Lilian W. Komo ${ }^{1} \&$ Isaac K. Ngugi ${ }^{2}$ \\ ${ }^{1}$ The Executive Business Centre, Lansdowne Campus, Bournemouth University, United Kingdom \\ ${ }^{2}$ The Business School, Talbot Campus, Bournemouth University, United Kingdom \\ Correspondence: Dr Isaac K. Ngugi, The Business School, Bournemouth University, Talbot Campus, Fern \\ Barrow, Poole, Dorset, BH12 5BB, UK. Tel: 44-120-2 96-3554. E-mail: ingugi@bournemouth.ac.uk
}

Received: November 19, 2012

Accepted: January 16, $2013 \quad$ Online Published: February 22, 2013

doi:10.5539/ijef.v5n3p49

URL: http://dx.doi.org/10.5539/ijef.v5n3p49

\begin{abstract}
The performance of banks and their effects on the global economy has been of interest to politicians, academicians, businesses and the general public especially in connection with the 2008/09 credit crisis. In particular, the extent to which the bank stock prices affected the national stock market indices in different countries before and during the crisis is unclear. It is also not clear whether the national stock markets of countries at different levels of economic development reacted differently to the crisis. This paper contributes to filling these gaps. It uses regression and correlation analytical techniques in the analysis of the impact and behaviour respectively. The results suggest that the behaviour of most of the stock market indices was similar regardless of the level of economic development. The mean stock market indices were statistically significantly higher before than during the credit crisis. Bank share prices were generally negatively correlated comparing the period before and during the crisis. Some countries were characterised by a few powerful banks that determined the course of the respective national stock market index. This has implications on policy and reveals the intervention points in regulating the performance of stock markets and stabilizing the financial sector.
\end{abstract}

Keywords: bank shares prices, stock markets, credit crises, economic development

\section{Introduction}

The 2008/09 financial crisis revealed that the power of globalisation can take a problem from one corner of the globe to multiple destinations (Chittedi, 2009). The crisis began in the US subprime mortgage sector, causing house prices to decline, economic activity to reduce and risk aversion to increase. It caused the failure of several large US based financial firms and had ramifications on household consumption (Naudé, 2009). The crisis rapidly spread to other parts in the world thereby causing failure of banks in Europe and decline in various stock indices as well as significant reductions in the market value of equities and commodities (Usman, 2010). The crisis spread further to other developed countries, as well as to emerging markets through a range of financial and real sector channels (Stephanou, 2009). The international trade declined and concomitantly the economies worldwide slowed down (World Bank, 2009). Governments were forced to make enormous financial commitments to mitigate the situation.

The crisis was caused by factors such as: poor supervision of banks and financial institutions; the extension of mortgage loans to borrowers at highly concessional terms; and excessive relaxation of fundamental rules and regulatory requirements for financial institutions (Lunogelo et al., 2010; Diamond and Rajan, 2009). Financial crises have been found to be related to a currency, a stock market or a banking crisis (Pericoli and Sbracia, 2003). The financial assets that are considered in this regard include; currencies (AuYong et al., 2004), bonds (Yang, 2005) and stock markets (Syriopoulos, 2007).

Following the 2008/09 crisis, the performance of banks and their effects on the global economy has become of much interest to politicians, academicians and the general public. Attempts have been made to examine aspects of the crisis a well as the measurement of systemic risk and regulatory structure (Dwyer, 2012) but there are still 
many lacunae. The crisis exposed major weaknesses in the extant repertoire of knowledge of the elements that drive global finance and revealed several knowledge gaps. For example, it is not clear to what extent the bank stock prices affected the national stock market indices in different countries. Also it is not clear if the national stock markets in various countries reacted differently to the crisis and if this varied with the levels of economic development. In line with these gaps, this study has four objectives: a) to examine the behaviour of national stock market indices across countries at different levels of economic development $b$ ) to estimate the impact of share prices of leading banks on respective national stock market index c) to compare the mean and behaviour of national stock market indices before (2006-2007) and during (2008-2009) the crisis d) to compare the mean and behaviour of bank stock prices across countries at different levels of economic development before (2006-2007) and during (2008-2009) the credit crisis.

The results of this study are relevant to many stakeholders. They are useful to academia in informing the efficient markets hypothesis - stock markets may be competitive or else they may be controlled by a few dominant firms. They are relevant to policy makers, managers of financial institutions such as banks and the regulators of financial markets especially in preparedness for and management of financial crises. The results are also beneficial to shareholders in informing them about the behaviour of stock markets before and during a financial crisis, which is relevant for their investment decisions.

\section{Theoretical Background}

\subsection{Significance of Banks to the World Economy}

Banks are significant to the world economy and make up a good portion of the equity market. The global financial sector has nearly $\$ 6$ trillion in market capitalization, implying that banks account for a significant share in the global economy. In 2008, the financial stock worldwide, specifically equity market capitalization and outstanding bonds and loans, was estimated at US\$ 175 trillion and this increased to US\$212 trillion by the end of 2010 (Roxburgh et al., 2011). Banks are instrumental in providing capital for infrastructure, innovation, job creation and overall prosperity while playing an integral role in society because they affect the spending of individual consumers and the growth of entire industries (Cogan, 2008). Banks play a delegated role of monitoring investments on behalf of investors (Diamond, 1984) and have the capability of reducing liquidity risk thereby creating investment opportunity (Diamond and Dybvig, 1983).

Stock returns of banks are critical to the future economic growth and prosperity of nations (Cole et al., 2008) as they are a key conduit of economic resources. It is a well-recognised fact that the development of the financial sector can make an important contribution to economic growth and poverty reduction. This is especially true in developing countries, given that their financial sectors are to a large extent not well developed, and without a well-functioning financial sector, economic development may be constrained (Cogan, 2008).

Stock prices of banks that are listed in the domestic stock exchanges reflect the performance of the banking sector in that country (Fariborz and Qiongbing, 2009). Furthermore, most stock market indicators tend to be highly correlated with banking sector development (Demirguc-Kunt and Levine, 1996). Also, volatility in the banking industry can be used to indicate the stability of a nation's banking sector performance (Fariborz and Qiongbing, 2009). Yartey and Adjasi (2007) establish that a percentage point increase in banking sector development increases stock market development in Africa by 0.59 percentage point, therefore in turn affecting macroeconomic stability and economic development.

\subsection{Relevance of Stock Markets}

Stock markets are relevant at least in: development of financial markets; promoting economic growth; and enabling fair resource custodianship and allocation. It is through stock markets that many firms are able to acquire capital quickly and efficiently (Kumar, 1984). The acquired capital is then invested or rather directed into profitable projects, consequently promoting sustainable investment growth. Indeed, stock market activities have been found to be positively correlated with investment (Tobin, 1969; Furstenberg, 1977).

The stock market accelerates economic growth by providing a boost to domestic savings and increasing the quantity and the quality of investment (Singh, 1997). It also encourages savings by providing individuals with an additional financial instrument that may better meet their risk preferences and liquidity needs (Levine and Zervos, 1998).

Stock markets have been found to have an influence on corporate governance (Abor et al., 2010). This is particularly by moderating the interests of shareholders vis-à-vis those of managers (ibid). Perhaps more benefits would be realized if markets were ideal, whereby prices provide accurate signals for resource allocation where firms can make production-investment decisions, and investors can choose among the securities that represent 
ownership of firms' activities under the assumption that securities prices at any time 'fully reflect' all available information (Beechey et al., 2000). Stock prices are related to the availability and cost of equity finance and they influence firms' investment decisions (Baker et al., 2003). Comparably, increases in the stock prices reflect availability of equity finance at relatively lower cost.

\subsection{Stock Market Indices}

A stock market index is a mean price for a group of stocks especially those larger in quantity. The stocks are usually on a particular stock exchange or across an investing sector. Indices are computed from stocks that have something in common. For instance, such stocks could be from the same exchange or from the same industry. Stock indices are indicators of the economic health of the particular industry that they represent (Vinod, 2009).

Vinod (2009) goes on to state that a stock market index tracks the performance of a specific basket of stocks over a given day or a given period of time. It may have many specific uses to different participants in the financial market place. One basic use of an index is in computing the total risk and return of the aggregate market portfolio for a given period of time to set a benchmark for evaluating the performance of actively managed individual portfolios. The study reckons that in some cases, the stock index is used as a proxy for market sentiments and investor confidence in the capital markets.

\subsection{Stock Prices}

Stock prices basically signify the perceived value of the investment or the company that they represent. They reflect the marginal productivity of capital and their increase consequently implies an increase in this productivity. In turn, an increase in the marginal productivity of capital is directly related to an increase in investment activities, and hence the positive correlation between changes in stock prices and investment growth. Changes in prices of stocks form an important component of variation in the market value of capital (Fama, 1981). Thus, there is a causal relationship between changes in the prices and in the market value of capital and investment. Since an increase in prices of stock is associated with an expansion in investment, stock markets have been found to significantly predict investment (Barro, 1990).

\section{Methodology}

\subsection{Sampling and Data Collection}

The data for this research comprises of the national stock market indices of countries at the three levels of economic development and bank stock prices of the leading banks listed in the respective stock markets. Purposively, three countries were selected from each category. Due to the author's particular interest in understanding more about Africa, the developing countries were selected only from the African continent. From each country, leading banks that are listed in the national stock market exchange were selected depending on level of capitalization as at the year 2010 and availability of data (Table 1). Leading banks registered at least within the five years (2006-2010) were selected so as to capture data before (2006-2007) and during (2008-2009) the credit crisis.

Data were extracted from Thomson Analytics, in US dollars. The Thomson Analytics database is professional, reliable and easily accessible compared to gathering the data directly from the individual stock markets. Extracting data from the individual stock markets is more expensive and time consuming.

The collected data comprises of national stock market indices and selected banks' share prices for the period 2006-2009. This period is relevant because it allows a comparative analysis for the period before the credit crisis (2006-2007) and during the crisis (2008-2009). The data included banks' stock market closing price and monthly price close data. The monthly price close data were for the stock indices. The use of monthly excess returns is justified considering that examination of co-movements of short-term returns, that is, daily or weekly returns, may understate the degree of integration due to non-synchronous trading and non-overlapping trading hours across different markets (Karolyi and Stulz, 1996). Furthermore, concerning the potential long-run nature of convergence and the co-integration analysis for common trends, it has been found that it is less the sample interval than the time span which plays an important role in detecting co-dependencies (ibid). 
Table 1. Selected countries, stock markets and banks

\begin{tabular}{|c|c|c|c|c|}
\hline $\begin{array}{l}\text { Level of } \\
\text { economic } \\
\text { development }\end{array}$ & Country & Stock market & Stock market index & Banks \\
\hline \multirow[t]{3}{*}{$\begin{array}{l}\text { Developing } \\
\text { countries }\end{array}$} & Kenya & Nairobi Stock Exchange & NSE & $\begin{array}{l}\text { Barclays Bank of Kenya Ltd, Kenya } \\
\text { Commercial Bank Ltd, Standard } \\
\text { Chartered Bank Ltd., NIC Bank Ltd, and } \\
\text { National Bank of Kenya Ltd }\end{array}$ \\
\hline & Nigeria & $\begin{array}{l}\text { Nigerian stock exchange } \\
\text { (NSE) }\end{array}$ & S\&P/IFCG & $\begin{array}{l}\text { First Bank of Nigeria Plc, Access Bank } \\
\text { plc, Guaranty Trust Bank Plc, Stanbic } \\
\text { IBTC Bank Plc, United Bank for Africa } \\
\text { (UBA) Plc. }\end{array}$ \\
\hline & Egypt & Egyptian stock exchange & $\begin{array}{l}\text { The Egypt Morgan Stanley } \\
\text { Capital International (MSCI) }\end{array}$ & $\begin{array}{l}\text { Commercial International Bank Egypt, } \\
\text { Egyptian Gulf Bank, Export Development } \\
\text { Bank of Egypt and Faisal Islamic Bank of } \\
\text { Egypt. }\end{array}$ \\
\hline \multirow[t]{3}{*}{$\begin{array}{l}\text { Emerging } \\
\text { countries }\end{array}$} & China & $\begin{array}{l}\text { Shanghai Stock Exchange } \\
\text { (SSE) }\end{array}$ & $\begin{array}{l}\text { Shanghai Stock Exchange } \\
\text { Composite Index }\end{array}$ & $\begin{array}{l}\text { Bank of China, China Citic Bank, China } \\
\text { Construction Bank, China Merchants } \\
\text { bank and Industrial \& Commercial Bank. }\end{array}$ \\
\hline & Brazil & BM\&FBOVESPA & BOVESPA & $\begin{array}{l}\text { Banco Bradesco, Banco de Brasil, Itau } \\
\text { Unibanco and Santander Brazil. }\end{array}$ \\
\hline & India & Bombay Stock Exchange & BSE National Index & $\begin{array}{l}\text { HDFC Bank Limited, HSBC India, ICICI } \\
\text { Bank Limited, Punjab National Bank and } \\
\text { the State Bank of India. }\end{array}$ \\
\hline \multirow[t]{3}{*}{$\begin{array}{l}\text { Developed } \\
\text { countries }\end{array}$} & $\begin{array}{l}\text { United } \\
\text { Kingdom }\end{array}$ & London Stock Exchange & 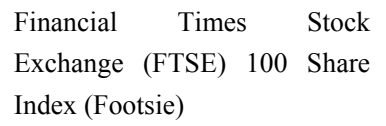 & $\begin{array}{l}\text { Barclays, HSBC, Lloyds, Royal bank of } \\
\text { Scotland and Standard Chartered. }\end{array}$ \\
\hline & Australia & $\begin{array}{l}\text { Australian Stock Exchange } \\
\text { market }\end{array}$ & ASX index & $\begin{array}{l}\text { Commonwealth Bank, Westpac, ANZ, } \\
\text { National Australia Bank and Bendigo and } \\
\text { Adelaide Bank. }\end{array}$ \\
\hline & $\begin{array}{l}\text { United } \\
\text { States of } \\
\text { America }\end{array}$ & NYSE & NYSE Composite Index & $\begin{array}{l}\text { Bank of America Corporation, HSBC } \\
\text { USA Inc., J. P. Morgan Chase \& Co., } \\
\text { Bank of New York Mellon Corporation } \\
\text { and Wells Fargo. }\end{array}$ \\
\hline
\end{tabular}

\subsection{Data Analysis}

In social science research, statistical techniques are considered a major tool for data analysis (Nachmias and Nachmias, 2008). In this study, SPSS is the main software that was used in data analysis and this largely involved regression and correlation analysis. The key variables in this study are the national stock market indices and the monthly banks' share prices. For analysis of the behaviour of national stock market indices across countries at different levels of development, correlation analysis was undertaken. To estimate the impact of share prices of leading banks on respective national stock market indices, regression analysis was carried out. Statistical tests were conducted to test the significance of the mean differences between the periods before (2006-2007) and during (2008-2009) the global financial crisis.

\section{Results and Discussion}

\subsection{Behaviour of National Stock Market Indices across Countries at Different Levels of Development}

In this section, the results and discussion with respect to the first objective of this study are presented. The behaviour of national stock markets across countries at different levels of economic development is examined. This was achieved by analysing the correlation between the national stock market indices across the countries during the four year period, 2006-2009 (Table 2). Pearson's correlation coefficient was estimated and this is appropriate in measuring the strength of the linear relationship between two variables (Burns and Burns, 2008; Stockburger, 1996), hence assessing herewith the similarity in the movements of the stock market indices across countries and testing whether this was statistically significant or not (Table 2). 
Table 2. Correlations between indices across stock markets in different countries

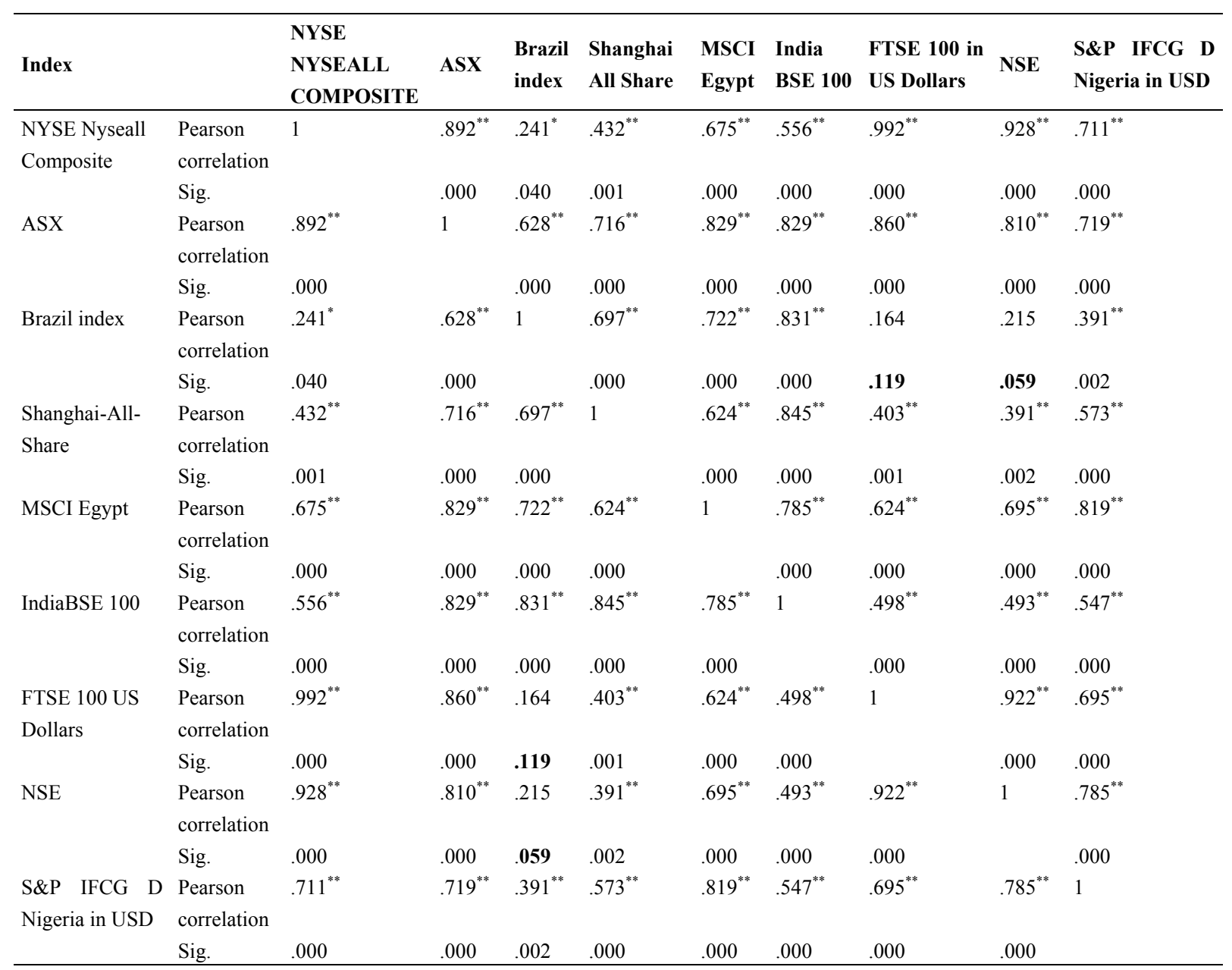

Notes: **. Correlation is significant at the 0.01 level (1-tailed). *. Correlation is significant at the 0.05 level (1-tailed). $\mathrm{N}=54$.

The results in Table 2 show that the Pearson correlation coefficient of all the indices is positive. Six out of the nine stock market indices are significantly positively correlated. However, in two instances the correlation was not significant. First is the behaviour of the Nairobi Stock Exchange index and the Brazilian Stock Market Index. The other instance is between the FTSE 100 and the Brazilian Stock Market Index. The Brazilian stock market index had the highest index throughout the period of analysis. The three countries that had the correlation coefficient not significant (Kenya, Brazil and UK) are at different levels of economic development. As expected, the highest positive correlation amongst the stock market indices was between America and United Kingdom, both of which are developed countries. In other words, FTSE 100 and the NYSE were the most highly correlated with a 0.992 Pearson correlation coefficient.

Amongst the developing (African) and developed countries, the Kenyan and American stock market indices showed the the highest correlation, with a Pearson correlation coefficient of 0.928 . On the other hand, between the developing and emerging countries, Egypt and India had the highest Pearson correlation coefficient, at 0.785 . Considering the developed and emerging economies, Australia and India had the highest Pearson correlation coefficient, estimated at 0.829 .

From the results in Table 2, it is evident that all the stock market indices were affected by the global financial crisis. All the indices were significantly positively correlated at least with the USA index. There is a convergence between the findings and theory in that, regardless of the country's level of development, there was a correlation in behaviour in most indices considering the pre and during the global financial crisis periods. This is consistent with Efficient Market Hypothesis since it may be an indication that the stock market indices were reacting to the news of a failing global economy. Furthermore, during a crisis, markets tend to strongly influence each other (Malliaris and Urrutia, 1992; Arshanapalli and Doukas, 1993; Gklezakou and Mylonakis, 2009). 
From the analysis (Table 2), it is a surprise that the stock market indices of Kenya (NSE) and UK (FTSE 100) had the second highest correlation (the highest was between NYSE and FTSE). This contradicts the findings of some studies that suggest that the less developed markets are relatively isolated from the capital markets of other countries and they have a relatively low correlation with markets in the developed countries (Chien-Chiang et al., 2010). However, the results of our study generally show that the stock market indices exhibited the same efficient market hypothesis regardless of the country's level of economic development. This could be an indication of how increasingly the world had become globalised and effects from one part of the world can easily diffuse to the other ends. Furthermore, crises seem to create excessive correlations between countries. Researchers call this contagion. A shock in one market leads investors to withdraw funds from other markets because of irrational fears and thus leads to unusually high co-movements of asset prices (Dutt and Mihov, 2008).

\subsection{Impact of Share Prices of Leading Banks on Respective National Stock Market Indices}

In this section, the results and discussion with respect to the second objective of this study are presented. The impacts of share prices of leading banks on respective national stock market index are estimated. This was done on per country basis and involved estimation of regression equations with the national stock market index as the dependent variable and the leading banks' share prices as the independent variables.

\subsubsection{Impact of Developed Countries Banks' Share Prices on the Respective Stock Market Index}

Equations 2, 4 and 6 shows the estimated regression models that illustrate the impact of developed countries banks' share prices on the respective stock market index.

Australia

Specified regression model:

$$
Y_{A U \text { STRALIA }}=\beta_{O}+\beta_{A N Z} P_{A N Z}+\beta_{B E N} P_{B E N}+\beta_{C B A} P_{C B A}+\beta_{N A B} P_{N A B}+\beta_{W B C} P_{W B C}+\varepsilon
$$

Results:

$$
Y_{\text {AUSTRALIA }}=-460.502-128.101_{A N Z-A U}+122.500_{B E N-A U}+92.235_{N A B-A U}+186.718_{W B C-A U}+\varepsilon
$$

Four out of the five Australian banks significantly influenced the ASX index. Amongst them, only ANZ-AU influenced negatively. CBA-AU was the only bank that did not have a significant impact on the Australian Stock Exchange. WBC-AU had the greatest impact $(\beta=187)$. The estimated model explains $94 \%$ of the variations in the index, as indicated byR Square.

USA

Specified regression model:

$$
Y_{U S A}=\beta_{O}+\beta_{B o A} P_{B o A}+\beta_{B N Y M} P_{B N Y M}+\beta_{H S B C} P_{H S B C}+\beta_{J P M-N} P_{J P M-N}+\beta_{W F} P_{W F}+\varepsilon
$$

Results:

$$
Y_{U S A}=-388.257+148.893_{B N Y M}+86.093_{H S B C-U S A}+\varepsilon
$$

Only two banks were found to significantly impact on the NYSE index at $95 \%$ confidence interval, namely the Bank-NY Mellon $(\rho<.000)$ and HSBC USA $(\rho<.000)$, with the Bank NY Mellon having a greater impact as evidenced by the respective coefficient $(\beta=149)$. The estimated model explains $94 \%$ of the variations in the national stock market index, as indicated by the $\mathrm{R}$ Square. The share prices of the other three banks (BoA, JPM-N and WF) did not have a significant impact on the NSE index at $95 \%$ confidence interval.

$U K$

Specified regression model:

$$
\begin{aligned}
Y_{K}=\beta_{O}+\beta_{B A R C-L N} P_{B A R C-L N} & +\beta_{H S B C-L N} P_{H S B C-L N}+\beta_{L L O Y-L N} P_{L L O Y-L N}+\beta_{R B S-L N} P_{R B S-L N} \\
& +\beta_{S T A N-L N} P_{S T A N-L N}+\varepsilon
\end{aligned}
$$

Results:

$$
Y_{U K}=25.535-1.687_{B A R C-L N}+1.185_{H S B C-L N}+5.851_{L L O Y-L N}+1.864_{S T A N-L N}+\varepsilon
$$

Four banks were found to impact significantly on the FTSE 100 index at $95 \%$ confidence interval, namely the BARC-LN $(\rho<.041)$, HSBC-LN $(p<.014)$, LLOY-LN $(p<.008)$ and STAN-LN $(\rho<.000)$. However, Barclays affected the index negatively while the rest affected it positively, as evidenced by the respective signs of the coefficients. The estimates of the coefficients indicate that the share prices of LLOY-LN bank had a greater 
impact on the FTSE 100 index than the shares of HSBC, Barclays and Standard Chartered. The estimated model explains $98 \%$ of the variations in the national index. The share prices of RBS did not have a statistically significant impact on the FTSE 100 at 95\% confidence interval.

\subsubsection{Impact of Emerging Countries Banks' Share Prices on the Respective National Stock Index}

Equations 8, 10 and 12 are the estimated regression models showing the impact of emerging countries banks' share prices on the respective stock market index.

Brazil

Specified regression model:

$$
Y_{K}=\beta_{O}+\beta_{\text {ITAU UNI }} P_{\text {ITAU UNI }}+\beta_{\text {SAN-BR }} P_{\text {SAN-BR }}+\beta_{\text {BBAS3-BR }} P_{B B A S 3-B R}+\beta_{\text {BBDCA-BR }} P_{\text {BBDCA-BR }}+\varepsilon
$$

Results:

$$
Y_{B R A Z I L}=-3495.049+913.868_{\text {ITAU UNIBANCO }}+1418.830_{B B D C 4-B R}+\varepsilon
$$

Two banks impacted significantly on the Brazil national stock market index at $95 \%$ confidence interval. These were ITAU UNIBANCO $(\rho<.002)$ and BBDC4-BR $(\rho<.000)$. Both affected the index positively. The coefficients indicate that the share prices of BBDC4-BR bank had a greater impact on the Brazilian national index than the shares of ITAU UNIBANCO. The estimated model explains $96 \%$ of the variations in the index. The share prices of SAN-BR and BBAS3-BR banks did not have a significant impact on the Brazilian index at $95 \%$ confidence interval.

\section{China}

Specified regression model:

$$
Y_{K}=\beta_{O}+\beta_{B o C} P_{B o C}+\beta_{C C B} P_{C C B}+\beta_{C C o n B} P_{C C o n B}+\beta_{C M B} P_{C M B}+\beta_{I C B} P_{I C B}+\varepsilon
$$

Results:

$$
Y_{\text {CHINA }}=-29.013+194.441_{\text {CHINA CITIC BANK }}+67.510_{\text {CHINA MERCHANTS BANK }}+349.809_{\text {Bank of BoC }}+\varepsilon
$$

Three banks were found to significantly impact on the Shanghai All Share index at $95 \%$ confidence interval. These were the China Citic Bank $(\rho<.001)$, China Merchants Bank $(\rho<.004)$ and Bank of China BoC $(\rho<.049)$. All the three banks affected the Shanghai All Share index positively. The coefficients indicate that the share prices of Bank of China had the greatest impact on the index. The estimated model explains $97 \%$ of the variations in the index. The share prices of the other banks (China Construction Bank and Industrial \& Commercial Bank) did not have a significant impact on the Shanghai All Share index at $95 \%$ confidence interval.

India

Specified regression model:

$$
\begin{aligned}
Y_{K}=\beta_{O}+\beta_{H D F C-B Y} P_{H D F C-B Y}+ & \beta_{H S B C I N D I A} P_{H S B C I N D I A}+\beta_{I C I C I-B Y} P_{I C I C I-B Y}+\beta_{P N B-B Y} P_{P N B-B Y} \\
& +\beta_{S B I-B Y} P_{S B I-B Y}+\varepsilon
\end{aligned}
$$

Results:

$$
Y_{I N D I A}=28.349+3.315_{H D F C-B Y}+4.258_{H S B C I N D I A}+3.369_{\text {ICICI-BY }}-3.929_{P N B-B Y}+\varepsilon
$$

Four out of five banks were found to impact significantly on the India BSE 100 index at $95 \%$ confidence interval. Unlike the other banks (ICICI-BY, HSBC INDIA and HDFC-BY), the share prices of PNB-BY bank had a negative impact on the India BSE 100 index. The estimated model is strong as it explains $97 \%$ of the variations in the index.

\subsubsection{Impact of Developing Countries Banks' Share Prices on the National Stock Index}

Equations 14, 16 and 18 shows the estimated regression models that reflects the impact of developing countries banks' share prices on the national stock market indices.

Nigeria

Specified regression model:

$$
\begin{array}{r}
Y_{K}=\beta_{O}+\beta_{A C C E S S B A N K-L A} P_{A C C E S S B A N K-L A}+\beta_{\text {FIRSTBANK-LA }} P_{\text {FIRSTBANK-LA }}+\beta_{\text {GUARANTY-LA }} P_{\text {GUARANTY-LA }}+\beta_{\text {Stanbic }} \\
{ }_{\text {IBTC-LA }} P_{\text {Stanbic IBTC-LA }}+\beta_{U B A-L A} P_{U B A-L A}+\varepsilon
\end{array}
$$


Results:

$$
Y_{\text {NIGERIA }}=51.142+357.859_{\text {FIRSTBANK-LA }}+1322.847_{\text {STANBIC IBTC-LA }}+374.759_{\text {UBA-LA }}+\varepsilon
$$

Three banks out of the five were found to impact significantly on the Nigeria Stock Exchage index at $95 \%$ confidence interval, namely the FIRSTBANK-LA $(\rho<.000)$, Stanbic IBTC-LA $(\rho<.001)$ and UBA-LA $(\rho<.029)$. The coefficients indicate that the share prices of Stanbic IBTC-LA bank had the greatest impact on the national index. The estimated model explains $95 \%$ of the variations in the index. The share prices of the other two banks (ACCESSBANK-LA and GUARANTY-LA) did not have a significant impact on the index at $95 \%$ confidence interval although they had positive coefficients.

\section{Kenya}

Specified regression model:

$$
Y_{K}=\beta_{O}+\beta_{K C B} P_{K C B}+\beta_{B B K} P_{B B K}+\beta_{N B K} P_{N B K}+\beta_{N I C} P_{N I C}+\beta_{S C B K} P_{S C B K}+\varepsilon
$$

Results:

$$
Y_{K}=-14.604-47.352 P_{N I C}+29.273 P_{S C B K}+\varepsilon
$$

Only two banks out of the five were found to impact significantly on the Nairobi Stock Exchange index at $95 \%$ confidence interval. These were the NIC $(\rho<.001)$ and SCBK $(\rho<.000)$. Surprisingly, NIC affected the index negatively while the SCBK affected it positively, as evidenced by the respective signs of the coefficients $\left(\beta_{\mathrm{NIC}}=.-47.352, \beta_{\mathrm{SCBK}}=29.273\right)$. As shown by the values of the coefficients, the share prices of NIC bank had a greater impact on the national index than the shares of SCBK. The estimated model explains $87 \%$ of the variations in the index. The share prices of the other three banks (BBK, KCB and NBK) did not have a significant impact on the national index at $95 \%$ confidence interval although they had positive coefficients.

Egypt

Specified regression model:

$$
Y_{K}=\beta_{O}+\beta_{C I B E} P_{C I B E}+\beta_{E G B E-C I} P_{E G B E-C I}+\beta_{E D B E} P_{E D B E}+\beta_{F I B} P_{F I B}+\varepsilon
$$

Results:

$$
Y_{E G Y P T}=54.092+15.734_{C I B E}+25.325_{E D B E}+11.193_{F I B}+\varepsilon
$$

In Egypt, three out of the four banks influenced significantly the national index. These were; Commercial International Bank Egypt $(p<.002)$, Export development bank $(p<.022)$ and the Faisal Islamic Bank $(p<.003)$. Both banks affected the stock market positively. The coefficients show that the share prices of CIBE had a greater impact $(\beta=16)$ on the stock market index than the share prices of FIB $(\beta=11)$. The estimated model explains $86 \%$ of the variations in the index. On the other hand, the share prices of the Egyptian gulf bank did not have a significant impact on the Egyptian stock market index at $95 \%$ confidence interval although they had positive coefficients.

In general, given the share prices of the banks whose coefficient were significant, the estimated models can be used to predict the respective national stock market index. The countries that had most of the banks in their chosen samples having a statistically significant impact on their stock market indices include Australia, United Kingdom and India. These countries had four out of five banks significantly affecting their national stock market indices. Closely following were Egypt and Nigeria, both with three banks affecting the index of their respective stock markets. On the other hand, America, China, Brazil and Kenya all had only two banks whose share prices statistically significantly affected the stock market indices.

\subsection{Comparison of the National Stock Market Indices Prior and during the Credit Crisis}

In this section, the results and discussion with respect to the third objective of this study are presented. This relates to the comparison of the national stock market indices before (2006-2007) and during (2008-2009) the credit crisis.

\subsubsection{Mean Differences of the National Stock Market Indices before and during the Crisis}

In Table 3, a paired sample t-test was carried out to test the mean differences between stock market indices before and during credit crisis. The table shows a paired sample t-test value associated with the $p$-value and other statistics. The results reveal that NYSE, Brazil index, ASX, NSE and FTSE all had a statistically significant mean difference at $95 \%$ confidence interval comparing the periods before and during the credit crisis. This implies that these indices were most affected in responding to the news of the credit crisis and therefore they serve as empirical evidence that the efficient market hypothesis discussed in the literature review chapter is still valid. 
Table 3. Paired samples statistics showing the mean difference between national stock market indices and average bank share prices before and during the crisis

\begin{tabular}{|c|c|c|c|c|c|c|c|}
\hline \multirow[b]{2}{*}{ Country } & \multicolumn{5}{|c|}{ Stock market indices } & \multicolumn{2}{|c|}{ Average bank share prices } \\
\hline & $\begin{array}{r}\text { Mean } \\
\text { difference }\end{array}$ & Std. Deviation & $\begin{array}{r}\text { Sig. } \\
\text { (2-tailed) }\end{array}$ & df & $\begin{array}{r}\text { Mean } \\
\text { difference }\end{array}$ & Std. Deviation & $\begin{array}{r}\text { Sig. } \\
\text { (2-tailed) }\end{array}$ \\
\hline USA & $2009.790 *$ & 2058.666 & 0.000 & 23 & $-11.516^{*}$ & 7.516 & 0.000 \\
\hline Australia & $767.415^{*}$ & 1585.640 & 0.026 & 23 & $-5.552 *$ & 6.365 & 0.000 \\
\hline UK & $-33.532 *$ & 30.956 & 0.000 & 23 & $-5.296 *$ & 3.756 & 0.000 \\
\hline Brazil & $-6476.536^{*}$ & 10882.254 & 0.008 & 23 & -0.153 & 3.452 & 0.830 \\
\hline India & 5.769 & 66.678 & 0.676 & 23 & 1.225 & 6.594 & 0.372 \\
\hline China & -17.522 & 252.168 & 0.737 & 23 & 0.088 & 0.523 & 0.418 \\
\hline Egypt & -4.476 & 121.427 & 0.858 & 23 & 0.052 & 2.210 & 0.920 \\
\hline Kenya & $18.505^{*}$ & 27.170 & 0.003 & 23 & -0.014 & 0.464 & 0.882 \\
\hline Nigeria & -23.455 & 356.511 & 0.750 & 23 & -0.057 & 0.143 & 0.065 \\
\hline
\end{tabular}

*Significant at 0.05 level of significance.

\subsubsection{Behaviour of the National Indices before and during Credit Crises}

Correlation analysis was carried out in order to identify if there was any statistically significant change in behaviour of the national stock market indices before and during the credit crisis. Table 4 indicates that the stock market indices for four countries out of the nine had statistically significant correlation for the period before and during the crisis. All the correlations were negative except that of Brazil and India, probably an indication that the credit crises spread at differential times across different countries. Else, this could be an indication that some countries were hit harder than others. The two positively correlated coefficients were not statistically significant and hence the observed phenomenon may have been a matter of chance. The correlation for the indices before and after crisis was not statistically significant for the countries in the emerging markets.

Table 4. Paired samples correlation analysis of stock market indices and mean bank share prices before and during the crisis

\begin{tabular}{|c|c|c|c|c|c|}
\hline \multirow[b]{2}{*}{ Country } & \multirow[b]{2}{*}{$\mathrm{N}$} & \multicolumn{2}{|c|}{$\begin{array}{c}\text { Correlation of stock market indices before and } \\
\text { during the crisis }\end{array}$} & \multicolumn{2}{|c|}{$\begin{array}{c}\text { Correlation of mean bank stock prices before } \\
\text { and during the crisis }\end{array}$} \\
\hline & & $\begin{array}{c}\text { Pearson correlation } \\
\text { coefficient }\end{array}$ & Sig. & $\begin{array}{c}\text { Pearson correlation } \\
\text { coefficient }\end{array}$ & Sig. \\
\hline USA & 24 & $-.668^{*}$ & .000 & $-.724 *$ & .000 \\
\hline Australia & 24 & -.316 & .133 & -.007 & .976 \\
\hline UK & 24 & $-.702 *$ & .000 & $-.715^{*}$ & .000 \\
\hline Brazil & 24 & .115 & .591 & .147 & .492 \\
\hline India & 24 & .041 & .848 & .350 & .094 \\
\hline China & 24 & -.040 & .853 & -.087 & .687 \\
\hline Egypt & 24 & -.349 & .095 & $-.481 *$ & .037 \\
\hline Kenya & 24 & $-.909 *$ & .000 & $-.870 *$ & .000 \\
\hline Nigeria & 24 & $-.827 *$ & .000 & -.136 & .525 \\
\hline
\end{tabular}

Note: *Significant at 0.05 level of significance

Those indices that were statistically significant were negatively correlated. This implies that during the period before crisis, they moved in one direction and for the period during the crisis, they moved in the opposite direction. Comparing the two periods, the statistically significant correlated indices were NYSE (USA), NSE (Kenya), FTSE (UK) and S\&P IFCG (Nigeria). The stock market index with the strongest correlation was the NSE with a correlation of -.909 while the index with the weakest significant correlation was NYSE (-.668). This implies that the Nairobi Stock Exchange had the biggest change and appears to have been affected more than all the other national stock market indices in this sample. This is extraordinary considering that Kenya is a developing country that is quite distanced from the origin or epicentre of the credit crisis for instance in terms of economic growth, industrialization and overall economic integration. This is however consistent with Mwega's (2010) findings that Kenya's stock exchange was the worst hit by the credit crisis considering the African 
countries, with the NSE 20 -Share Index slumping by $35 \%$ in 2008 . Kenya was followed by Nigeria and Mauritius which are countries that for long have liberalised their capital markets.

Given that five out of nine stock market indices had statistically significant mean difference and the behaviour of four indices were statistically different comparing the pre and during the recessionary periods, this confirms the findings of Modi et al. (2010) that the increasing integration among the national stock exchanges is an indication of the ease of transmission of financial instabilities from international to domestic markets (financial contagion). They explain that despite the fact that the poorest countries in the developing world, particularly in Africa, do not have sophisticated financial markets, thus are not susceptible to direct financial contagion, does not prevent the dangers arising from contagion. This is because the overall collapse in confidence in the financial system world-wide raises borrowing costs sharply, cuts back revenues and threatens the solvency of domestic financial systems even in low-income countries that may be poorly integrated into the international market. Moreover, the banking sector in some developing nations is largely under foreign ownership. This may imply that decisions taken by foreign banks to withdraw credit might compound difficulties caused by deleveraging especially as banks sharply curtail lending activities and focus on consolidating the financial accounts of the parent company (Mold et al., 2009).

4.4 Comparison of the Bank Stock Prices Reactions across Countries at Different Levels of Development before and during the Credit Crisis

In this section, the results and discussion with respect to the fourth objective of this study are presented. The hypothesis that there is no significant difference in the mean and behaviour of bank stock prices across countries at different levels of development before (2006-2007) and during (2008-2009) the credit crisis is tested.

\subsubsection{Mean Differences of Average Bank Share Prices before and after Credit Crises}

For the bank share prices, data was taken for the 2006-2009 period. The average share prices, considering the banks in our sample, for each month per country were calculated. A comparison between the periods 2006-2007 and 2008-2009 was done using a paired samples t-test (Table 3). Generally, the average share prices of most of the banks reduced during the credit crisis compared to the positions held before the crisis. The developed countries (Australia, America and United Kingdom) had the most notable changes as their bank stock price averages reduced the most compared to the other countries and the mean difference in each case was significantly different.

\subsubsection{Behaviour of Average Bank Share Prices Prior and during the Recessionary Period}

Table 4 presents the paired samples correlations of average bank stock prices across countries at different levels of economic development before (2006-2007) and during (2008-2009) the financial crisis. The statistics indicate that four out of nine average bank share prices had statistically significant correlation for the period before and during the crisis. Those that were statistically significant were negatively correlated. The statistically significant correlated average bank share prices included those of the banks in USA, UK, Kenya and Egypt. The country with the strongest correlation in the average share prices for the two periods was Kenya with a correlation of -.870 while that with the weakest correlation was U.K (-.715). The banks share prices of the developed and developing countries were particularly significantly affected by the crisis. The global financial crisis stemmed from the US-based transnational financial institutions and spread quickly beyond the US. The credit crisis first spread to other developed countries and further to other regions including the developed countries (Roach, 2009).

\section{Conclusions and Recommendations}

This study achieved the four objectives set forth in the introduction. The results suggest that, the behaviour of most of the stock market indices was similar regardless of the level of economic development. Some countries were characterised by only a few powerful banks that determined the course of the national stock index. In other words, only a few banks had significant impact on the national stock market index and the estimated models were a good fit, each explaining more than $80 \%$ of the variations in the index. This reveals the intervention points if policy makers were to stabilise the stock markets. National stock market regulators could set an early warning department for detecting the early signs in the movement of the indices and establishing the cause. If the movement is negative and caused by movement in shares of one or a few organisations, then corrective actions could be targeted to such companies. A kitty could be established for purchasing shares of the affected companies as a corrective measure and dispose them once stability is attained. The stock market index and average bank share prices for most countries had statistically significant correlation before and during the 2008/09 credit crisis but moving in opposite direction. 
It is evident from the results that regardless of the level of development of the countries, they all had some reaction to the news of a looming credit crisis. Following the spread of the financial crisis to different parts of the globe, the bank-share prices and the stock market indices registered changes to varying degrees. These responses to the global crisis signify efficiency of the stock markets and this is consistent with the efficient market hypothesis. The knowledge and measurement of the level of the efficiency of the stock market is essential to policy makers, investors, and other major players that are involved in ensuring long-term real capital in a country. As Alam and Uddin, (2009) note, across the globe, a mature level of the stock market efficiency is perceived as a barometer of the economic health and prospect of a nation. It is also a reflection of the confidence of both the domestic and global investor.

There is a need to reform the existing international financial architecture in order to reduce the likelihood of financial crises and to manage them better. These reforms should be characterised by a full participation and representation of countries at all levels of economic development. Despite the challenges posed by financial globalization, it would be useful to design and implement a new approach to capital regulation and supervision if future stability of the global financial system is to be guaranteed. This concurs with Moshirian's (2008) call for stronger and more effective international institutions that are capable of monitoring the activities of international financial institutions. Furthermore, strengthening capital restrictions and official supervisory powers can improve the efficient operations of banks (Chortareas et al 2012).

Usman (2010) reckons that the incidences of financial crises have put the international financial system in question. Perhaps the structures and principles of Islamic finance might remedy the situation, or probably help to avert a global financial crisis in future. This financial system offers more ethical and efficient alternative to the conventional interest-based financial system. It deters interest and introduces in its place the principle of risk and reward-sharing. It also tends to daunt short selling because one may only sell something that he/she owns (ibid). The system is considered a value-based one and which primarily aims at enhancing moral and material wellbeing of the individual as well as of the society as a whole (Ahmed, 1994). It may be worthwhile to borrow some principles about the frameworks that are used by this system to uphold ethical business practices in finance. With the innovation of financial products still to continue, is it possible to learn and maybe use the technicalities that are employed in coming up with ethically sound financial products and contracts. The financial industry could borrow a leaf from the good qualities of Islamic finance as it seeks to perfect ethical business practices in the global financial markets. Besides, financial institutions should always recognise that they have fiduciary responsibility to act in the best interests of the consumer, while regulation and supervision of financial markets should enhance trust in financial institutions and in the financial system.

\section{Limitations and Suggestions for Further Research}

Some banks did not have complete data for the entire period. For instance in the case of Brazil, data for the bank Banco Santander was missing for the period between January 2006 and February 2007, whereas for Egypt, all the four banks had some data missing between the years 2006-2008. This may cause a slight bias. This study is limited to only three countries for each level of economic development. This means that there is scope in enlarging this to a larger sample. In addition, non-probability sampling was used to select the countries and stock exchanges from which data was extracted, therefore the objectivity and representativeness of the study may have been compromised. Further research could adopt alternative sampling techniques. In some cases (e.g. Australian), some banks were found to significantly influence the national index positively (despite the recession) while others influenced negatively. It would be interesting to undertake in-depth case studies focused on such unexpected or exemplar cases and to draw lessons.

\section{References}

Abor, J., Adjasi, C. K. D., Bokpin, G. A., \& Osei, K. A. (2010). Do Emerging Financial Markets Matter in Investment Opportunity Set? A Dynamic Panel Analysis. Journal of Money, Investment and Banking, 4.

Adjasi, C. K. D., \& Biekpe, N. (2009). Do Stock Markets Matter in Investment Growth in Africa? The Journal of Developing Areas, 43, 109-120. http://dx.doi.org/10.1353/jda.0.0032

Ahmed, Z. (1994). Islamic Banking: State of the Art. Islamic Economic Studies, 2, 1-34.

Alam, M. M., \& Uddin, G. S. (2009). Relationship between Interest Rate and Stock Price: Empirical Evidence from Developed and Developing Countries. International Journal of Business and Management, 4.

Anmar, P., \& Beer, J. D. (2010). Comparing the South African Stock Market's Response to Two Periods of Distinct Instability - the 1997/8 Asian and Russian Crisis and the Recent Global Financial Crisis. Retrieved from 
http://ec.ut.ee/eaces2010/artiklid/Pretorius\%20de\%20Beer-Comparing\%20the\%20South\%20African.pdf

Arshanapalli, B., Doukas, J., \& Lang, L. (1993). International Stock Market Linkages: Evidence from the Preand Post-October 1987 Period. Journal of Banking and Finance, 17, 193-208. http://dx.doi.org/10.1016/0378-4266(93)90088-U

Auyong, H., Gan, C., \& Treepongkaruna, S. (2004). Cointegration and Causality in the Asian and Emerging Foreign Exchange Markets: Evidence from the 1990s Financial Crises. International Review of Financial Analysis, 13, 479-515. http://dx.doi.org/10.1016/j.irfa.2004.02.024

Barro, R. J. (1990). The Stock Market and Investment. Review of Financial Studies, 3, 115-131. http://dx.doi.org/10.1093/rfs/3.1.115

Beechey, M., Gruen, D., \& Vickery, J. (2000). The Efficient Market Hypothesis: A Survey. In Economic Research Department. R. B. O. A. (Eds.). Retrived from: http://web.cenet.org.cn/upfile/93098.pdf

Boshoff, W. H. (2006). The Transmission of Foreign Financial Crises to South Africa: A Firm-Level Study. Journal for Studies in Economics and Econometrics, 30, 61-85.

Burns, R. B., \& Burns, R. A. (2008). Business Research Methods and Statistics Using Spss. London, SAGE.

Chien-Chiang, L., Jun-De, L., \& Chi-Chuan, L. (2010). Stock Prices and the Efficient Market Hypothesis: Evidence from a Panel Stationary Test with Structural Breaks. Japan and the World Economy, 22, 49-58. http://dx.doi.org/10.1016/j.japwor.2009.04.002

Chittedi, K. R. (2009). Global Stock Markets Development and Integration: With Special Reference to Bric Countries. MPRA Paper. Retrieved from http://mpra.ub.uni-muenchen.de/18602/1/MPRA_paper_18602.pdf

Chortareas, G., Girardone, C., \& Ventouri, A. (2012). Bank supervision, regulation, and efficiency: Evidence from the European Union. Journal of Financial Stability, 8, 292-302. http://dx.doi.org/10.1016/j.jfs.2011.12.001

Cogan, A. (2008). The Cluster Approach to Economic Growth. Business Growth Initiative Technical Brief No. 7. ed. Washington, D.C, Weidemann Associates, Inc. Retrieved from: http://tinyurl.com/3jekqj

Cole, R., Moshirian, F., \& Wu, Q. (2008). Bank Stock Return and Economic Growth. Journal of Banking \& Finance, 32, 995-1007. http://dx.doi.org/10.1016/j.jbankfin.2007.07.006

Demirguc-Kunt, A., \& Levine, R. (1996). Stock Markets, Corporate Finance and Economic Growth: An Overview. The World Bank Economic Review, 10, 223-239. http://dx.doi.org/10.1093/wber/10.2.223

Diamond, D. (1984). Financial Intermediation and Delegated Monitoring. Review of Economic Studies, 51, 393-414. http://dx.doi.org/10.2307/2297430

Diamond, D., \& Dybvig, P. (1983). Bank Runs, Deposit Insurance and Liquidity. Journal of Political Economy, 91, 401-419. http://dx.doi.org/10.1086/261155

Diamond, D., \& Rajan, R. (2009). The Credit Crisis: Conjectures About Causes and Remedies. AER Papers and Proceedings. forthcoming. http://dx.doi.org/10.1257/aer.99.2.606

Dutt, P., \& Mihov, I. (2008). Stock Market Co-movements and Industrial Structure.

Dwyer, G., Tabak, B., \& Vilmunen, J. (2012). The financial crisis of 2008, credit markets and effects on developed and emerging economies. Journal of Financial Stability, 8, 135-137. http://dx.doi.org/10.1016/j.jfs.2012.03.001

Fama, E. P. (1981). Stock Returns, Real Activity, Inflation, and Money. American Economlc Review, 71, 545-565.

Fariborz, M., \& Qiongbing, W. (2009). Banking Industry Volatility and Banking Crises. International Financial Markets, Institutions and Money, 19, 351-370. http://dx.doi.org/10.1016/j.intfin.2008.02.002

Furstenberg, V. (1977). Corporate Investment: Does Market Valuation Matter in the Aggregate? Brookings Papers on Economic Activity, 2.

Gklezakou, T., \& Mylonakis, J. (2009). Interdependence of the Developing Stock Markets, before and During the Economic Crisis: The Case of South Europe. Journal of Money, Investment and Banking, 70-78.

Karolyi, G. A., \& Stulz, R. M. (1996). Why Do Markets Move Together? An Investigation of Us-Japan Stock Return Comovements. Journal of Finance, 51, 951-986. 
http://dx.doi.org/10.1111/j.1540-6261.1996.tb02713.x

Levine, R., \& Zervos, S. (1998). Stock Markets Banks and Economic Growth. American Economic Review, 88, 537-58.

Lunogelo, H. B., Mbilinyi, A., \& Hangi, M. (2010). Global Financial Crisis Discussion Series Paper 20: Tanzania Phase 21. Global Financial Crisis Discussion Series. London, Overseas Development Institute. Retrieved from: http://www.odi.org.uk/resources/download/4738.pdf

Malliaris, A. G., \& Urrutia, J. L. (1992). The International Crash of October 1987: Causality Tests. Journal of Financial and Quantitative Analysis, 27, 353-364. http://dx.doi.org/10.2307/2331324

Modi, A. G., Patel, B. K., \& Patel, N. R. (2010). The Study on Co-Movement of Selected Stock Markets. International Research Journal of Finance and Economics. Retrieved from http://www.eurojournals.com/IRJFE_47_15.pdf

Mold, A., Paulo, S., \& Prizzon, A. (2009). Taking Stock of the Credit Crunch: Implications for Development Finance and Global Governance. OECD Development Centre. http://dx.doi.org/10.1787/224377364587

Moshirian, F. (2008). Financial Services in an Increasingly Integrated Global Financial Market. Journal of Banking and Finance, 32, 2288-2292. http://dx.doi.org/10.1016/j.jbankfin.2008.03.003

Mwega, F. M. (2010). Global Financial Crisis: Kenya Phase 2 Discussion Series. London, Overseas Development Institute. Retrieved from: http://www.odi.org.uk/resources/download/3312.pdf

Nachmias, C. F., \& Nachmias, D. (2008). Research Methods in the Social Sciences. New York, Worth.

Naudé, W. (2009). Fallacies About the Global Financial Crisis Harms Recovery in the Poorest Countries. Retrieved from https://www.cesifogroup.de/pls/guestci/download/C-ESifo\%20Forum\%202009/CESifo\%20Forum\%204/20 09/forum4-09-focus1.pdf

Pericoli, M., \& Sbracia, M. (2003). A Primer on Financial Contagion. Journal of Economic Surveys, 17, 571-608. http://dx.doi.org/10.1111/1467-6419.00205

Roach, S. S. (2009). A Lethal Shakeout. Foreign Policy. Washington, DC. Retrieved from http://www.foreignpolicy.com/story/cms.php?story_id=4592\&.

Roxburgh, C., Lund, S., \& Piotrowski, J. (2011). Mapping global capital markets 2011. McKinsey Global Institute.

Singh, A. (1997). Financial Liberalization, Stock Markets, and Economic Development. The Economic Journal, 107, 771-782. http://dx.doi.org/10.1111/j.1468-0297.1997.tb00042.x

Smith, M. J. (1998). Social Science in Question. London: Sage.

Stephanou, C. (2009). Dealing with the Crisis: Taking Stock of the Global Policy Response Crisis Response Policy Brief 1. Retrieved from http://papers.ssrn.com/sol3/papers.cfm?abstract_id=1427416

Stockburger, D. W. (1996.) Introductory Statistics: Concepts, Models, and Applications. Missouri State University.

Syriopoulos, T. (2007). Dynamic Linkages between Emerging European and Developed Stock Markets: Has the Emu Any Impact? International Review of Financial Analysis, 16, 41-60. http://dx.doi.org/10.1016/j.irfa.2005.02.003

Tobin, J. (1969). A General Equilibrium Approach to Monetary Theory. Journal of Money Credit and Banking, 1, 15-29. http://dx.doi.org/10.2307/1991374

Usman, M. (2010). Global Financial Crisis: Its Impact on Developing Countries and Lessons for Pakistan. IPRI Journal, 1, 93-118.

Vinod, T. (2009). Importance of Stock Market and How Stock Market Is Important for Countries Economy. Retrieved from http://www.sharetipsinfo.com/economy-stock-market.html

World Bank. (2009). The Global Financial Crisis. Washington, DC, World Bank.

Yang, J. (2005). Government Bank Market Linkages: Evidence from Europe. Applied Financial Economics, 15, 599-610. http://dx.doi.org/10.1080/09603100500056775

Yartey, C. A., \& Adjasi, C. K. D. (2007). Stock Market Development in Sub-Saharan Africa: Critical Issues and Challenges. IMF Working Paper African Department. Retrieved from http://ssrn.com/abstract=1094214 